\title{
Al-Madãris
}

VOL. 1, NO. 12020

E-ISSN: 2745-9950

https://journal.staijamitar.ac.id/index.php/almadaris

\section{MAKNA BUDAYA DALAM LIRIK LAGU RANUP KARYA RAFLI KANDE: KAJIAN ETNOLINGUISTIK}

\author{
Ninin Herlina \\ Sekolah Tinggi Agama Islam (STAI) Jamiatut Tarbiyah Lhoksukon \\ herlynasahara@gmail.com
}

\begin{abstract}
This research is an ethnolinguistic study that discusses how the lingual form and cultural meaning in the lyrics of the song 'Ranup' by Rafli Kande, an Acehnese artist. The research objectives are detailed, among others; l) to describe the lingual forms in Ranup's song lyrics, 2) to interpret the cultural meaning in Ranup's song lyrics. This study uses a qualitative approach with descriptive type methods. The data collection method is done by using documentation. The data analysis method used in this research is the intralingual matching method and the estralingual matching method. The data analysis technique in this research is done by; 1) identifying data, 2) classifying data, 3) interpreting data. Presentation of the analysis results in this study using informal methods and formal methods. The results of this study are as follows: (1) the lingual form in the Ranup song lyrics is in the form of words, phrases, clauses, sentences, and discourses. (2) the cultural meaning contained in the lyrics of the Ranup song is the cultural meaning of respect, the meaning of sacred culture, the cultural meaning of conveying kindness, the cultural meaning of guidance, the cultural meaning of togetherness.
\end{abstract}

Keywords: Cultural Meanings, Lingual, Song Lyrics, Ethnolinguistics

Al-Madãris, Volume 1 (1), 2020 


\section{A. Pendahuluan}

Kehidupan sosial masyarakat tidak lepas dari berkembangnya unsur-unsur kebudayaan. Makna budaya itu sendiri bisa diperoleh tidak hanya dalam tindak keseharian atau adat istiadat masyarakat. Budaya merupakan hasil karya suatu masyarakat tertentu. Masyarakat dan budaya memiliki hubungan timbal balik. Masyarakat menghasilkan budaya dan suatu budaya menentukan karakter dan pola hidup suatu masyarakat. Sejatinya manusia atau masyarakat menciptakan budaya demi kemaslahatan hidupnya. Sehingga suatu kebudayaan kerap menjadi suatu kemegahan di daerah tertentu. Suatu kebudayaan kerap menjadi kekayaan tak ternilai dalam suatu masyarakat tertentu.

Kebudayaan tidak saja berkaitan dengan bentuk peradaban yang bersimbolkan bangunan megah. Akan tetapi suatu sikap yang mendarah daging dalam suatu masyarakat di daerah tertentu merupakan suatu kebudayaan yang bernilai. (Cohen \& Varnum, 2016) Sebagaimana halnya dalam suatu upacara adat, nilai kebudayaan sangat dijunjung tinggi. Para seniman turut mengambil bagian dalam memperkenalkan nilai budaya bagi generasi, misalnya dengan menciptakan tarian maupun lirik lagu yang menggambarkan nilai kebudayaan. Banyak penelitian yang menggambarkan pesan yang disampaikan dalam suatu tarian. (Safitri, Supadmi, \& Fitri, 2017) Sama halnya dengan terciptanya lirik lagu Ranup karya seorang seniman Aceh yang cukup terkenal baik di tingkat nasional maupun internasional. Rafli merupakan sosok seniman yang tidak sembarangan dalam menciptakan lagu. Semua lagu-lagunya sarat dengan pesan moral serta membangkitkan kembali nilai-nilai sejarah. Lagu Ranup merupakan salah satu karyanya yang menggambarkan pola adat masyarakat Aceh dalam memuliakan tamu. Lirik lagu Ranup tersebut menjelaskan tata cara seseorang memanjakan tamu dengan hidangan khusus yaitu Ranup. Ranup dikenal dengan nama daun sirih.

Lirik lagu tersebut tentu sangat menarik di kalangan orang Aceh. Ketika suatu budaya diangkat dalam bentuk lagu maka dipastikan setiap generasi akan turut memahami tentang suatu budaya daerahnya berikutnya para orang tua akan semakin merasa bangga dengan bentuk budaya yang mereka miliki. Sesungguhnya para seniman merupakan aktor sastra yang cukup lihai dalam mempertahankan nilai-nilai keindahan dalam kehidupan.(Milfont \& Schultz, 2016) Maka penelitian ini menjadi sangat menarik dan penting demi memahami sebuah lirik lagu yang sarat makna budaya. Sehingga secara tidak langsung pekerjaan ini menjadi satu misi terbaik peneliti dalam mengembangkan nilai-nilai sastra. Disamping itu penelitian ini akan menjadi satu khasanah keilmuan dalam memahami satu tradisi di daerah Aceh dalam menyambut kedatangan tamu. Seyogyanya ini merupakan hal unik dalam kehidupan masyarakat Aceh.

\section{B. Review Literatur}

Penelitian tentang budaya merupakan bagian dari kajian sastra. Karena sastra memberi keindahan dalam kehidupan manusia. Sementara budaya memberi pandangan terhadap nilai-nilai atau norma-norma. Dalam mempelajari normanorma budaya mewakili pendekatan lintas-disiplin, multi-level kritis yang ideal untuk memahami budaya dan memanfaatkan potensinya untuk perubahan

Al-Madãris, Volume l (1), 2020 
positif.(Gelfand \& Jackson, 2016) Budaya memiliki pengaruh penting dalam kelestarian kehidupan manusia. Bahkan cara individu berhubungan dengan alam di pandang sebagai suatu motif budaya. Artinya, budaya menjadi kajian dalam melihat bagaimana manusia memperlakukan lingkungan kehidupannya. (Milfont $\&$ Schultz, 2016)

Penelitian tentang budaya juga dikembangkan dengan melihat perbedaan secara holistik dari dari budaya timur dan barat. (Cohen \& Varnum, 2016). Dalam penelitian lain dijelaskan bahwa budaya turut berperan dalam menyatukan sejumlah bidang ilmu sosial yang berbeda. Sehingga disimpulkan bahwa aturan pembelajaran budaya, kognisi bahasa dan penalaran tentang etnis sosial menggambarkan suatu pendekatan kekuatan. (Moya \& Henrich, 2016). Budaya dan bahasa tidak dapat dipisahkan, banyak penelitian yang mencoba melestarikan suatu bahasa dengan tetap melestarikan budaya daerah atau ritual daerah setempat. Sebagaimana yang dilakukan Munyengsana dalam mempertahankan budaya di Rwanda agar tetap bisa berinteraksi secara global yaitu dengan mempertahankan bahasa (Patrick Munyensanga, 2017)

Disamping itu penelitian terbaru turut menggambarkan betapa evolusi budaya berperan dalam perkembangan sifat-sifat struktural dari bahasa seseorang. Evolusi budaya telah digunakan untuk menjelaskan asal-usul struktur dalam sinyal linguistik, dan dalam pemetaan antara sinyal dan makna. Evolusi budaya dinilai menjadi proses yang cukup kuat dalam mempengaruhi proses evolusi bahasa. (Steels, 2011)

Demikian eratnya hubungan budaya dan bahasa. Hal ini juga di dukung dengan penelitian yang menjelaskan betapa budaya dan bahasa adalah paling penting dalam memahami hakikat kognisi manusia. Artinya budaya dan bahasa sangat diperlukan dalam mempertimbangkan interaksi yang kompleks antara budaya dan bahasa untuk memberikan gambaran yang komprehensif tentang bagaimana bahasa dan budaya mempengaruhi pemikiran. (Jiang, 2000).

Maka, pembelajaran budaya sejatinya bertujuan untuk membentuk pola pikir manusia. Seorang seniman sekalipun tentu menggunakan karya seninya sebagai alat untuk menambah wawasan atau daya fikir setiap individu, salah satunya lirik lagu. Lirik lagu diciptakan sebagai suatu pesan tertentu yang diharapkan mempengaruhi fikiran yang mendengarnya disamping untuk kebutuhan hiburan. Lirik lagu menjadi suatu kajian tradisi lisan yang semakin populer di kalangan masyarakat. (Pudentia, 2008)

Penelitian tentang pengaruh lirik lagu dalam setiap bidang kehidupan telah banyak diteliti. Ucik meneliti simbol dan makna kebangsaan dalam lirik lagu-lagu Dolanan di Jawa Tengah dan implementasinya dalam dunia pendidikan. (Fuadhiyah, 2011) sementara Muhammad menggunakan kajian etnomusikologi dalam meneliti tentang seni budaya dan karakter bangsa. (Takari, 2010). Namun penelitian yang paling relevan terkait penggunaan lirik lagu atau syair juga dilakukan dalam meneliti pengaruh syair terhadap tatanan kehidupan masyarakat. Syair tari tradisional dianggap sangat berpengaruh dalam membentuk tatanan kehidupan masyarakat khususnya di daerah. Karena dalam syair tari tradisional ditemukan banyak pesan-pesan kehidupan yang bermakna dalam menata kehidupan (Zuriana, 2011) Selanjutnya juga penelitian dilakukan untuk mengkaji 
nilai-nilai kultural dalam lirik lagu 'Banyuwangen'. Penelitian ini merupakan suatu kajian tradisi lisan yang terdapat di daerah Banyuwangi, Jawa Timur. Lirik lagu tersebut dipandang bersifat menghibur dan juga memiliki nilai-nilai budaya yang perlu dicermati. (Lestari, 2013)

Tidak jauh berbeda dengan penelitian-penelitian sebelumnya, lirik lagu Ranup juga memiliki nilai-nilai budaya yang penting untuk di kaji sebagai suatu kekhasan masyarakat Aceh dalam memuliakan tamu. Kekhasan Ranup ini juga terdapat dalam bentuk tarian tradisionalnya yang dikenal dengan tarian Ranup Lampuan. Nilai-nilai budaya dalam tarian tersebut juga sudah dikaji dalam penelitian Susanto dengan judul 'Dance Ranup Lampuan: Exploration Genius Aceh Movement and Expression Female Body Beauty Values in Culture Peumulia Jamee'.(Riezal, Joebagio, \& Susanto, 2018) Penelitian lain terkait Ranup juga dilakukan dalam mengkaji bagaimana bentuk penyajian tari ranup lampuan sebagai suatu studi komparatif dan memiliki makna filosofis antara sanggar lempia dan sanggar nurul alam. (Pakpahan, 2016) Pesan dalam tarian Ranup lampuan juga sudah di teliti dengan memahami bentuk pesan dalam syair tarian tersebut. (Akbar, Maryani, \& Si, n.d.)

Peneliti disini mengambil kajian lirik lagu Ranup karya Rafli Kande sebagai suatu kajian yang memiliki makna budaya dengan mempertimbangkan kepopuleran lagu tersebut yang di arrangement ulang dengan musik yang kekinian. Sehingga kepopuleran lagu tersebut menjadi semakin menarik bagi generasi muda. Generasi muda ini pula yang diharapkan mampu memahhami nilai atau makna budaya dari lirik lagu tersebut.

Maka, peneliti merumuskan pertanyaan penelitian sebagai berikut :

1. Bagaimana bentuk lingual dalam lirik lagu Ranup karya Rafli Kande?

2. Bagaimana makna budaya dalam lirik lagu Ranup karya Rafli Kande?

\section{Metodelogi}

Penelitian ini menggunakan pendekatan kualitatif dengan metode deskriptif. Data dalam penelitian ini dikumpulkan dengan menggunakan lirik lagu Ranup yang diperoleh dari internet. Lirik lagu Ranup merupakan data utama yang dianalisis untuk menemukan sejumlah makna budaya serta memperoleh bentuk lingual dari lirik-lirik tersebut. Metode analisis data yang digunakan dalam penelitian ini adalah metode padan intralingual dan metode padan ekstralingual. Padan intralingual adalah metode analisis data yang bersifat lingua, baik yang terdapat dalam satu bahasa maupun dalam beberapa bahasa yang berbeda Mahsun (2014: 117). Metode padan intralingual dalam penelitian ini digunakan untuk menemukan bentuk satuan lingual yang memiliki makna budaya. Sedangkan metode padan ekstralingual digunakan untuk menganalisis unsur bahasa yang bersifat ekstralingual, seperti menghubungkan masalah bahasa dengan hal yang berbeda diluar bahasa (Mahsun, 2014: 120). Teknik analisis data dalam penelitian ini dilakukan dengan cara ; 1) mengidentifikasi data, 2) mengklasifikasi data, 3) menginterpretasikan data. Penyajian hasil analisis dalam penelitian ini menggunakan metode informal dan metode formal.

Al-Madãris, Volume l (1), 2020 


\section{Pembahasan Hasil Penelitian}

Peneliti telah mendapatkan lirik lagu Ranup karya Rafli Kande dari media Internet. Lirik tersebut merupakan data utama yang akan di analisis dengan menggunakan kajian etnolinguistik.

\section{Bentuk Lingual Bermakna Budaya dalam Lirik Lagu Ranup}

\section{Bentuk Lingual Kata}

Dalam lirik lagu Ranup ditemukan satuan lingual bermakna budaya berbentuk kata depan. Berikut bentuk lingual bermakna budaya berbentuk kata dalam lirik lagu Ranup.

a. Kata 'Neu'

'Neu' ini merupakan padanan diawal kata yang ditujukan kepada yang lebih tua dengan tanda penghormatan. Penggunaan kata depan ini menunjukkan tingkat perlakuan yang sangat halus terhadap lawan bicara yang dituju. Dalam hal tertentu orang tua juga kerap menggunakan kata depan tersebut ketika berbicara dengan yang lebih muda untuk menunjukkan contoh bahasa halus dalam berbicara.

Neucok ranup nyopat hai

Ranup neu pajoh tanda mulia

Neu ci pajoh sigapu ile

Dalam penggalan lirik tersebut kata depan 'neu' menjadi sangat bermakna karena konteks berbicara adalah dengan para tamu. Para tamu merupakan orangorang yang sangat dihargai dan dihormati kehadirannya. Sehingga penggunaan bahasa disusun dengan sehalus mungkin. Neucok memiliki berarti silahkan ambil. b. Kata depan 'Geu'

Tidak jauh berbeda dengan 'neu', kata depan 'geu' juga digunakan untuk menunjukkan bentuk penuturan yang paling halus ketika berbicara dengan lawan bicara yang dihormati. Berikut contoh penggalan lirik lagu yang menggunakan kata depan 'geu'.

Adat geutanyo keu jame teuka

Geutanyo udep bek meukleeh meukleeh

'Geutanyoe' memiliki makna yang cukup halus untuk menunjukkan bentuk jamak, yang berarti 'kita'. Akan tetapi berbeda derajat kesantunannya ketika hanya menggunakan kata 'tanyoe', yang juga memiliki arti 'kita'.

\section{Bentuk Lingual Frasa}

Bentuk lingual kata dalam lirik lagu Ranup juga bisa berarti menjadi suatu bentuk lingual frasa. Seperti penggalan berikut:

Neucok ranup nyopat hai

Ranup neu pajoh tanda mulia

Neucok dan neu pajoh merupakan bentuk lingual frasa yang berbentuk perintah. Secara leksikal neucok merupakan suatu kegiatan yang memerintahkan seseorang untuk mengambil sesuatu. Neucok berarti silahkan ambil. Neu pajoh berarti silahkan makan. 


\section{Bentuk Lingual Kalimat}

Bentuk lingul dalam kalimat yang bermakna budaya terdapat dalam beberapa penggalam lirik lagu.

Ranup lam bate peumulia jamee (Daun sirih dalam batu untuk memuliakan tamu)

Adat geutanyo keu jame teuka (Adat kita ketika tamu datang)

Neu ci pajoh sigapu ile (Coba di makan dulu sedikit kapur sirihnya)

ie ranup klat jeut keu peunawa (Air sirih kelat bisa jadi penawar)

Kalimat-kalimat di atas merupakan bentuk lingual kalimat yang memiliki makna bahwa ranup itu adalah adat orang Aceh untuk memuliakan tamu dan ranup juga bisa dijadikan obat penawar. Bate secara leksikal merupakan batu. Namun dalam hal ini batu yang dimaksud adalah batu khusus yang digunakan untuk menumbuk daun sirih yang dicampur pinang dan kapur.

\section{Bentuk Lingual Wacana}

Wacana adalah satuan bahasa yang terlengkap. Wacana dikatakan lengkap karena di dalamnya terdapat konsep, gagasan, pikiran atau ide yang utuh, yang dipahami oleh pembaca (dalam wacana tulis) atau oleh pendengar (dalam wacana lisan)tanpa keraguan apapun. Berikut penggalan lirik lagu Ranup yang memiliki bentuk lingual wacana.

Peunajoh aceh meu macam bagoe

Peunajoh jameun sampo inoe hat

Ranup seulaseh ngon pineung maweo

Gapu ngon gambee lengkap keu syarat

Ranup lam bate peumulia jamee

Adat geutanyo keu jame teuka

Neu ci pajoh sigapu ile

ie ranup klat jeut keu peunawa

Lirik tersebut memiliki kesatuan makna utuh yang menggambarkan adat masyarakat Aceh dalam memuliakan tamu. Bait tersebut juga menunjukkan bahwa Ranup bukanlah makanan biasa saja, tapi Ranup bisa menjadi obat untuk penyakit tertentu. Maka, wacana ini menjadi informasi utuh dalam suatu lagu yang sarat makna.

\section{Makna Budaya dalam Lirik Lagu Ranup}

\section{Makna Budaya Penghormatan}

Dalam lagu Ranup terdapat budaya luhur yang menunjukkan kekhasan masyarakat Aceh dalam menyambut tamu. Budaya ini secara turun menurun di abadikan oleh masyarakat Aceh sebagai identitas yang penuh makna. Dalam lirik lagu Ranup terdapat bentuk penghormatan yang sangat dalam kepada tamu. Bentuk penghormatan ini merupakan budaya yang melekat dalam adat masyarakat Aceh.

Neucok ranup nyopat hai 
Ranup neu pajoh tanda mulia

Neu ci pajoh sigapu ile

Ranup neupajoh beujet keu ubat

Makna budaya dalam lagu Ranup menunjukkan bentuk penghormatan bahkan dari judulnya 'Ranup' sudah merupakan satu simbol penghormatan dan kemuliaan di tradisi masyarakat Aceh. Ranup neu pajoh tanda mulia artinya Sirih yang anda makan adalah tanda kemuliaan.

\section{Makna Budaya Obat Penawar Tradisional}

Neu ci pajoh sigapu ile (Coba di makan dulu sedikit kapur sirihnya)

ie ranup klat jeut keu peunawa (Air sirih kelat bisa jadi penawar)

Piyoh piyoh piyoh..... piyoh (silahkan duduk...silahkan duduk...silahkan duduk)

Neucok ranup nyo pat hai (Ini sirih silahkan diambil)

Ranup neu pajoh beujet keu ubat (Sirih yang anda makan semoga bisa jadi obat)

Selain budaya memuliakan tamu, dalam lirik lagu Ranup juga menunjukkan khasiat Ranup sebagai suatu budaya masyarakat Aceh dalam mengobati penyakit tertentu dengan menggunakan obat tradisional salah satunya yaitu Ranup. Ranup (daun sirih) ini banyak digunakan untuk mengobati penyakit yang diderita anakanak ataupun orang tua. Air daun sirih juga dijadikan obat penawar penyakit tertentu. Bagi orang-orang yang tidak tertarik dengan obat-obatan rumah sakit, mereka lebih memilih obat tradisional yang berasal dari tumbuh-tumbuhan alami. Ini merupakan satu budaya yang patut dipertahankan dan diperkenalkan kepada generasi sekarang.

\section{Makna Budaya Penyampaian Kebaikan}

Pesan dalam lirik lagu adalah untuk suatu kebaikan. Lagu Ranup juga menyerukan suatu kebaikan yang di lantunkan menggunakan bahasa pantun.

Peuleuhen leuheun takoh bak kaye (Berhati-hati menebang pokok kayu)

Tinggai peureudee teumpat lheuk kutru (Sisa pokok batang untuk bertengger burung perkutut)

Bek ta boeh boeh keu rakan dilee (Jangan tinggalkan kawan/rekan yang dulu)

Jampang ta lakee ranup si gapu (Sesekali kita bisa meminta sedikit sirih dan kapur)

Lirik di atas di gubah dari rima sebuah pantun yang sarat dengan pesan moral. Kata 'peuleuheun-leuheun' secara leksikal artinya berhati-hatilah yang menunjukkan aktivitas mengerjakan sesuatu. Ini merupakan bentuk seruan kebaikan ketika melakukan suatu kegiatan yang dalam hal ini adalah menebang pokok kayu.

'Bek' secara leksikal adalah seruan melarang untuk melakukan sesuatu yang tidak baik. Dalam hal ini larangan yang dimaksud adalah tidak boleh meninggalkan atau melupakan teman lama. Secara implisit ini merupakan suatu penyampaian kebaikan yang berarti kita harus terus menjaga silaturahmi. 


\section{Makna Budaya Kebersamaan}

Dalam lirik lagu Ranup juga terdapat budaya kebersamaan yang sangat penting untuk dicermati. Penggalan berikut menunjukkan pesan untuk menjaga kebersamaan dan tetap menjaga silaturahmi.

Bek ta boeh boeh keu rakan dilee (Jangan tinggalkan kawan/rekan yang dulu)

Jampang ta lakee ranup si gapu (Sesekali kita bisa meminta sedikit sirih dan kapur)

Hai rakan loen dum ureung aceh (Wahai rekan/teman saya semua orang Aceh)

Ranup sigapu neu pajoh sigra (Sirih sekapur segeralah anda makan)

Geutanyo udep bek meukleeh meukleeh (Kita hidup jangan berpisah-pisah)

Gaseh meugaseh bila meubila (Kasih mengasihi bela membela)

Secara leksikal 'geutanyoe' memiliki arti kata ganti jamak yang menyebutkan kebersamaan, yaitu 'kita'. 'Bek meukleh meukleh' adalah bentuk larangan jangan berpisah-pisah. Ini juga menunjukkan anjuran untuk hidup bersama-sama. 'Gaseh meugaseh bila meubila', ini adalah kalimat kebersamaan yang menunjukkan betapa pentingnya kasih mengasihi dan bela membela. Penggalan lirik lagu ini memberi pesan moral yang secara implisit juga menggambarkan bahwa budaya kebersamaan dalam masyarakat Aceh sangat di perhatikan.

\section{E. Kesimpulan}

Masyarakat Aceh memiliki kekhasan budaya dalam menyambut tamu mereka. Hal ini dikenal dengan istilah peumulia jamee (memuliakan tamu). Kegiatan ini merupakan bentuk pelestarian budaya yang harus dipahami oleh setiap generasinya. Pemberian Ranup (sirih) merupakan bagian dari memuliakan tamu.

Dalam lirik lagu Ranup karya Rafli Kande terdapat susunan lingual yang menunjukkan makna budaya. Bentuk lingual bisa ditemukan dalam kosa kata, frasa, kalimat dan wacana yang tersusun. Sementara makna budaya yang terdapat dalam lirik lagu Ranup terdiri dari; 1) makna budaya penghormatan, 2) makna budaya obat penawar tradisional, 3) makna budaya penyampaian kebaikan, dan 4) makna budaya kebersamaan. Makna budaya tersebut

\section{BIBLIOGRAFI}

Akbar, M., Maryani, A., \& Si, M. (n.d.). Pesan Dalam Tari Ranup Lampuan.

Cohen, A. B., \& Varnum, M. E. W. (2016). Beyond East vs. West: Social class, region, and religion as forms of culture. Current Opinion in Psychology, 8, 5-9.

Fuadhiyah, U. (2011). Simbol dan Makna Kebangsaan dalam Lirik Lagu-Lagu Dolanan di Jawa Tengah dan Implementasinya dalam Dunia Pendidikan. Lingua, $7(1)$.

Gelfand, M. J., \& Jackson, J. C. (2016). From one mind to many: the emerging science of cultural norms. Current Opinion in Psychology, 8, 175-181.

Jiang, W. (2000). The relationship between culture and language. ELT Journal, 54(4), 328-334.

Lestari, I. W. (2013). Nilai-Nilai Kultural Dalam Lirik Lagu "Banyuwangen ": Kajian Tradisi Lisan.

Al-Madãris, Volume l (1), 2020 
Mahsun, 2014. Metode Penelitian Bahasa, Tahapan Strategi, Metode, dan Tehniknya. Jakarta: Raja Grafindo Persada.

Milfont, T. L., \& Schultz, P. W. (2016). Culture and the natural environment. Current Opinion in Psychology, 8, 194-199.

Moya, C., \& Henrich, J. (2016). Culture-gene coevolutionary psychology: cultural learning, language, and ethnic psychology. Current Opinion in Psychology, 8 , $112-118$.

Pakpahan, E. N. (2016). Bentuk Penyajian Tari Ranup Lampuan (Studi Komparatif dan Makna Filosofis Antara Sanggar Lempia dan Sanggar Nurul Alam. UIN Ar-Raniry Banda Aceh.

Patrick Munyensanga, M. (2017). OUR IDENTIFICATION THROUGH COMMON CULTURE AS SINGLE LANGUAGE UNIFIES US.

Pudentia, M. (2008). Metodologi kajian tradisi lisan (Vol. 20). Asosiasi Tradisi Lisan.

Purwantoro, dkk. 2012. Pedoman Umum Ejaan Bahasa Indonesia yang di Sempurnakan. Surabaya. Bintang Surabaya

Riezal, C., Joebagio, H., \& Susanto, S. (2018). Dance Ranup Lampuan: Exploration Genius Aceh Movement and Expression Female Body Beauty Values in Culture Peumulia Jamee. International Journal of Multicultural and Multireligious Understanding, 5(5), 146-155.

Safitri, M., Supadmi, T., \& Fitri, A. (2017). Bentuk Penyajian Tari Pelebat di Sanggar Lac Suku Alas Kabupaten Aceh Tenggara. Jurnal Ilmiah Mahasiswa Pendidikan Seni, Drama, Tari \& Musik, 2(2).

Soekanto, Soejono. 2012. Sosiologi Suatu Pengantar. Jakarta: Raja Grafindo Persada.

Steels, L. (2011). Modeling the cultural evolution of language. Physics of Life Reviews, $8(4), 339-356$.

Takari, M. (2010). SENI BUDAYA DAN KARAKTER BANGSA. Etnomusikologi, 10.

Zuriana, C. (2011). PENGARUH SYAIR TARI TRADISIONAL DALAM TATANAN KEHIDUPAN MASYARAKAT ACEH. Ceudah: Jurnal Ilmiah Sastra, 1(1), 33-41.

Yendra. 2016. Mengenal Ilmu Bahasa (Linguistik). Yogyakarta : Deepublish.

Al-Madãris, Volume l (1), 2020 